\title{
ASSESSMENT OF DNA VARIATIONS OF THE NOBLE CRAYFISH (ASTACUS ASTACUS L.) IN GERMANY AND POLAND USING INTER-SIMPLE SEQUENCE REPEATS (ISSRS)
}

\author{
H.K. SCHULZ (1), P. ŚMIETANA (2), R. SCHULZ (1)
}

(1) Zoological Institute, Technical University, Fasanenstrasse 3, D-38092 Braunschweig, Germany.

E-Mail: Holger.Schulz@tu-bs.de

(2) Department of Ecology, University of Szczecin, ul. Waska 13, 71-415 Szczecin, Poland.

Reçu le 7 janvier 2004

Accepté le 15 mars 2004

Received January 7, 2004

Accepted March 15, 2004

\begin{abstract}
Conservation of the endangered noble crayfish (Astacus astacus) requires preservation of existing populations and reintroduction into suitable habitats, as currently underway in several regional projects in Germany and Poland. Therefore, knowledge about the genetic variation between populations is vital but, unfortunately, still restricted. By means of ISSR-PCR (Inter-Simple Sequence Repeats - Polymerase Chain Reaction) eight stocks in Germany and Poland were analysed. These semi-arbitrary multiloci markers had not previously been used in population studies of the noble crayfish. A total of 22 unambiguous and polymorphic markers were detected to use in the subsequent statistical analysis. The number of polymorphic loci in one population ranged from 4 to 19 . Therefore the ISSR markers proved suitable for assessing within- and between-population DNA variations and establishing significant separation of most of the stocks. Shannon's Index, a relative estimate of genetic diversity within populations, ranged from 0.06 to 0.51 . UPGMA cluster analysis based on pairwise ROGERS' (1972) genetic distance revealed two main clusters corresponding to populations sampled in the western and eastern part of the study area. Results are relevant on the local, regional and supra-regional (landscape) level. The implications for conservational management and restocking programs are presented.
\end{abstract}

Key-words: Astacus astacus, conservation genetics, ISSR, landscape ecology.

\section{ESTIMATION DES VARIATIONS D'ADN DE L'ÉCREVISSE À PATTES ROUGES (ASTACUS ASTACUS L.) EN ALLEMAGNE ET EN POLOGNE PAR L'UTILISATION DES RÉPÉTITIONS SÉQUENTIELLES INTERNES SIMPLES (ISSRS)}

\section{RÉSUMÉ}

La conservation de l'écrevisse à pattes rouges (Astacus astacus) menacée nécessite la préservation des populations existantes et la réintroduction de spécimens dans des habitats favorables. Plusieurs projets régionaux tenant compte de ces nécessités sont actuellement mis en place en Allemagne et en Pologne. Pour une gestion pérenne de l'espèce, la connaissance de la variabilité génétique des populations est nécessaire. 
Huit populations ont été analysées par ISSR-PCR (Inter-Simple Sequence RepeatsPolymerase Chain Reaction). C'est la première fois que ces marqueurs semi-arbitraires et multiloci ont été utilisés pour l'étude des populations d'écrevisse à pattes rouges. Un total de 22 marqueurs non ambigus et polymorphes a été retenu pour cette étude. Le nombre de loci polymorphe par population varie de 4 à 19. Par conséquent, les marqueurs ISSR s'avèrent appropriés pour analyser la variabilité intra et inter populationnelles. L'index de Shannon's montre des valeurs de diversité intra populationnelle comprises entre 0,06 et 0,51. L'UPGMA basé sur les distances génétiques (ROGERS, 1972) révèle deux principaux groupes correspondant aux populations échantillonnées dans l'Ouest et l'est de l'aire géographique étudiée. Les résultats de structuration sont significatifs aux niveaux local, régional et supra-régional. Les implications pour la conservation et les programmes de repeuplement sont présentées.

Mots-clés: Astacus astacus, génétique de conservation, ISSR, écologie du paysage.

\section{INTRODUCTION}

The area of recent distribution of the noble crayfish Astacus astacus L. covers northern Greece, the Balkans, central and western Europe, Scandinavia as well as major parts of eastern Europe to the White Sea in the north (ALBRECHT, 1983; HOLDICH, 2002). Three subspecies are separated by KARAMAN (1962) and ALBRECHT (1983) on the basis of morphological criteria. Since the Middle Ages the noble crayfish was a commercial object throughout Europe; among the European crayfish species, this one has been most prominent as a delicacy and for medicinal purposes. This resulted in extensive translocation of crayfish and founding of new stocks (ALBRECHT, 1983). The construction of canals during the $18^{\text {th }}$ and $19^{\text {th }}$ Centuries promoted further expansion. For these reasons it is very complicated to reconstruct the post-glacial history of colonization for $A$. astacus. ALBRECHT (1983) presumed that during the last ice age $A$. astacus was restricted to a refugial zone in northern Greece and the Balkans. Therefore, ALBRECHT inferred a natural post-Pleistocene distribution of $A$. astacus in the Balkans (subspecies $A$. a. balcanicus), in the Ponto-Caspian region (A. a. colchicus) and in the Danube drainage system (A. a. astacus). However, the origin of the A. astacus populations in northern Germany and Eastern Europe is still not known.

Such information is important, because the noble crayfish $A$. astacus is recognised as a highly threatened species in Central and Eastern Europe (HOLDICH, 2002; VIGNEUX et al., 2002). Since the beginning of industrialisation in the $19^{\text {th }}$ Century the number of native crayfish stocks has been decreasing. The introduction of the crayfish plague accelerated this process dramatically, leading to the eradication of native crayfish in large areas of Europe (HAASE et al., 1989). A low capacity for natural dispersal of the noble crayfish and the interruption of gene flow by habitat alteration and expansion of nonindigenous crayfish species resulted in strong fragmentation of the relict populations. To counteract the still ongoing loss of native crayfish stocks, important measures are the protection of habitats and the restocking of suitable water bodies, and such measures are being undertaken in several local projects in Germany and Poland (DEHUS et al., 1999; ŚMIETANA et al., 2003). But as highlighted by several authors, the knowledge of genetic variations within and between remaining populations is an essential prerequisite for the protection of species (AVISE, 1994; RIFFEL and SCHREIBER, 1995; HAIG, 1998). Isolated populations may have evolved adaptations to their local environment. If those differences are not taken into account when stocking measurements are conducted, there is a danger that geographical variations of potential evolutionary significance may be neglected, as has been described in several cases (SKAALA et al., 1990; FERGUSON, 1990; HINDAR et al., 1991). For this reason, MORITZ (1994) suggested that animal populations with 
significant genetic differences may be considered as separate stocks and managed as distinct conservation units.

Since the mid-1980s scientists have tried to describe the genetic structure of freshwater crayfish species. A variety of methods have been applied. Early studies based on protein electrophoresis have shown only low levels of variation between populations of European freshwater crayfish (ATTARD and VIANET, 1985; FEVOLDEN and HESSEN, 1989; AGERBERG, 1990; FEVOLDEN et al., 1994). During the last decade molecular techniques revealing a higher degree of variability have been developed and applied successfully in population studies of freshwater crayfish. Genetic differentiation of populations had been assessed using mitochondrial DNA (SOUTY-GROSSET et al., 1997; GRANDJEAN and SOUTY-GROSSET, 2000; LARGIADER et al., 2000), RAPD-PCR (MACARANAS et al., 1995; SCHULZ, 2000; GOUIN et al., 2001), AFLP (FETZNER and CRANDALL, 1999) and microsatellites (GOUIN et al., 2000; EDSMAN et al., 2002; GOUIN et al., 2002). Phylogenetic studies (GRANDJEAN et al., 2000; MUNASINGHE et al., 2003), and reconstruction of the phylogeography (GRANDJEAN et al., 2001) were possible using mitochondrial DNA. Regarding European species, most of these studies focussed on the Austropotamobius pallipes (Lereboullet) species complex. Information on genetic structure of $A$. astacus is still scarce. Using RAPD-markers SCHULZ (2000) compared two stocks in northeastern Germany (Brandenburg), one in northwestern Germany and two stocks in southern Germany (Bavaria). All five stocks could be clearly distinguished, indicating a high geographic structuring of genetic diversity. EDSMAN et al. (2002) analysed microsatellite length variations in the ITS1 region of the rDNA and detected highly significant differences between most of the sampled Swedish populations.

In this study we applied a PCR-based, semi-arbitrary marker called Inter Simple Sequence Repeat (ISSR) (ZIĘTKIEWICZ et al., 1994; GUPTA et al., 1994) which assesses variation in the microsatellite regions. Simple sequence repeats (SSR) or microsatellites are short hypervariable stretches of DNA which are dispersed throughout the genome of eukaryotes. The amplification of the regions between two inversely orientated microsatellites with primers anchored within these elements leads to multilocus and highly polymorphous patterns. Like RAPD-PCR, this method does not need prior genomic information and only small quantities of template DNA are required. In addition, ISSR showed greater robustness in repeatability experiments across a wide range of PCR parameters (BORNET and BRANCHARD, 2001). The utility of this technique had been established for a wide range of applications from conservation biology to molecular ecology and systematics (WOLFE and LISTON, 1998). Nevertheless, it has so far been only rarely applied in animals (ABBOT, 2001).

The objective of the present study is to evaluate ISSR markers for population-level studies in freshwater crayfish and to assess the genetic diversity of the noble crayfish in its central area of distribution. This paper summarises initial results of the application of ISSR to analyse the genetic variation of noble crayfish populations in Germany and Poland.

\section{MATERIALS AND METHODS}

\section{Sample collection}

Leg muscle tissue samples were taken during 2001-2002 from 12-16 male specimens per stock, originating from 5 locations in Poland and 3 locations in Germany (Figure I). The sampling technique did not cause severe damage to the crayfish and the animals were returned to the place where they were caught. For preservation during shipping the tissue was placed in a $100 \mathrm{mM}$ Tris- $\mathrm{HCl}, 40 \mathrm{mM}$ EDTA, $0.2 \%$ SDS solution at pH 8.0 as recommended by KIRBY (1990). 


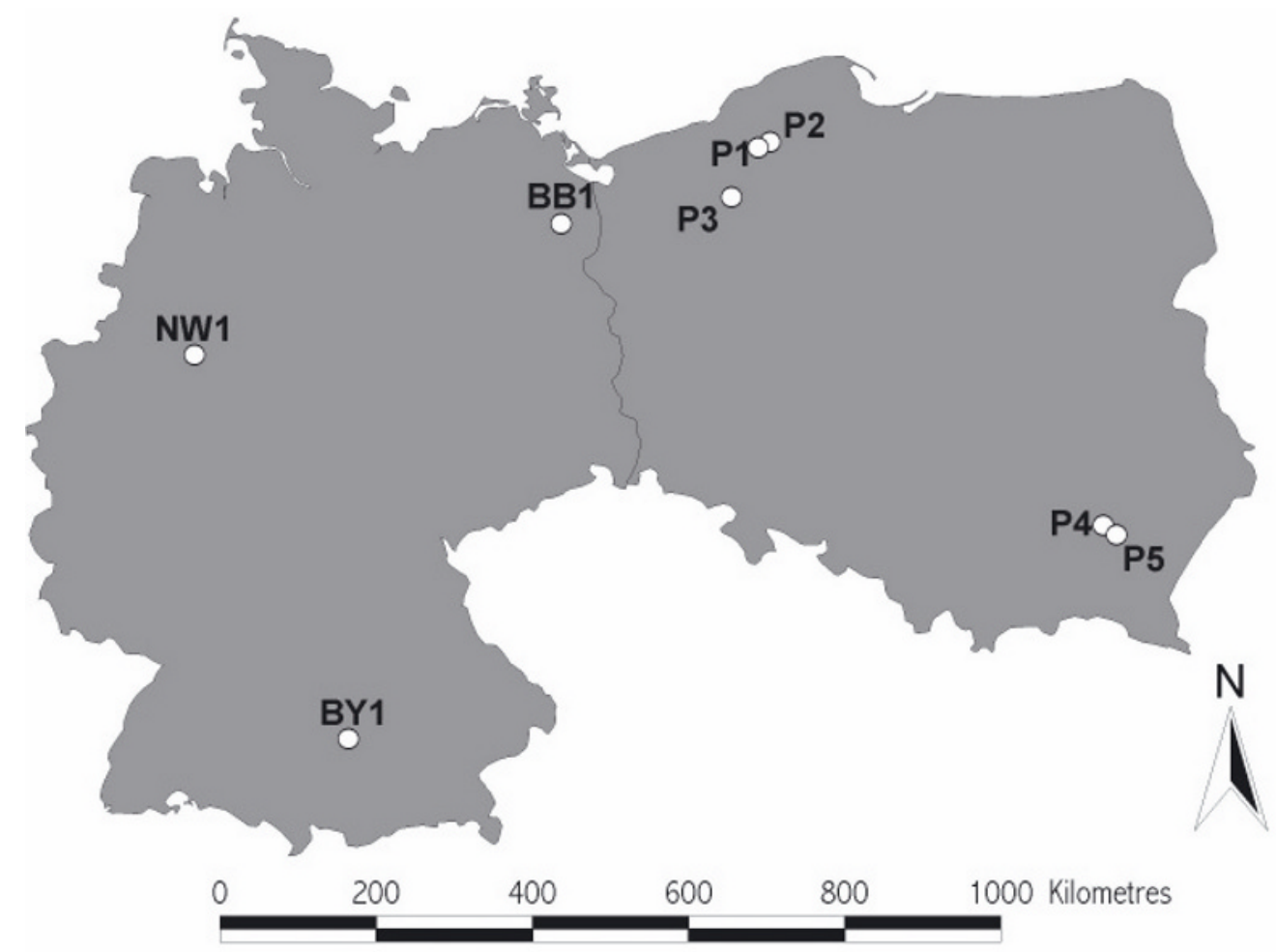

Figure 1

Localisation of the sample sites used for collection of animals for genetic analysis.

\section{Figure 1}

Localisation des sites d'échantillonage des animaux utilisés pour l'analyse génétique.

BB1, P1, P2 and P3 are lake populations in northeastern Germany (Brandenburg) and northwestern Poland (Pomorskie Lakeland), respectively. Lake P3 was restocked in 1996 with approximately 1300 specimens taken from P2 after a former population of A. astacus was assumed to have died out in lake P3. Both P4 and P5 are river populations in two different streams in southeastern Poland belonging to the drainage system of the river Wisłok. The samples BY1 and NW1 are taken from two hatcheries in northwestern Germany (North-Rhine Westphalia) and southern Germany (Bavaria), respectively. The hatcheries were both initially set up with specimens originating from local populations.

\section{Genomic DNA preparation and ISSR analysis}

DNA was extracted according to SAMBROOK and RUSSELL (2001). Tissues were homogenized with plastic pestles in a microcentrifuge tube containing $10 \mathrm{mM}$ Tris- $\mathrm{HCl}$ (pH 8.0), $1 \mathrm{mM}$ EDTA ( $\mathrm{pH} 8.0$ ), $0.1 \%$ SDS and $100 \mu \mathrm{g} / \mathrm{ml}$ proteinase K. Samples were incubated either for 3 hours at $55^{\circ} \mathrm{C}$ or for $16 \mathrm{~h}$ at $37^{\circ} \mathrm{C}$. DNase-free RNase was added to a final concentration of $20 \mu \mathrm{g} / \mathrm{ml}$ and the digest incubated for another $60 \mathrm{~min}$. After precipitation of the SDS by adding potassium acetate solution to a final concentration of $0.75 \mathrm{M}$ in respect of potassium and 1.25 $\mathrm{M}$ in respect of acetate, the DNA was precipitated with one volume of isopropanol. The pellet was washed with $70 \%$ ethanol, dried and redissolved in $10 \mathrm{mM}$ Tris- $\mathrm{HCl}(\mathrm{pH}$ 8.0).

PCR reactions were performed in a total volume of $25 \mu$ containing $0.5 \mathrm{u}$ Taq polymerase (PEQLAB, Germany), $20 \mathrm{mM}$ Tris- $\mathrm{HCl}$ (pH 8.55), $16 \mathrm{mM}(\mathrm{NH} 4)_{2} \mathrm{SO}_{4}, 0.1 \%$ Tween 20, $2 \mathrm{mM} \mathrm{MgCl} 2,200 \mu \mathrm{M}$ of each dNTP (PEQLAB, Germany), $0.2 \mu \mathrm{M}$ primer and 
20 ng template DNA. In the beginning 91 ISSR primers obtained from the University of British Columbia were screened for positive amplification results. 53 of them did not produce any amplification products, 7 produced poorly resolved banding patterns, and 21 produced clear-cut banding patterns. Those 21 primers were screened for populationlevel markers in 6 individuals from 3 geographically distant populations. Six primers were finally chosen to give polymorphic and reproducible banding patterns.

Three different cycling programmes were performed on a PERKIN ELMER 9600 thermal cycler to obtain optimal results for each primer: 1) 5 min at $94^{\circ} \mathrm{C}$ followed by 0 : $45 \mathrm{~min} / 94^{\circ} \mathrm{C}, 0: 45 \mathrm{~min} / 48^{\circ} \mathrm{C}, 1: 30 \mathrm{~min} / 72^{\circ} \mathrm{C}$ for 35 cycles and final extension of $7 \mathrm{~min} /$ $72^{\circ} \mathrm{C}$. 2) $5 \mathrm{~min}$ at $94^{\circ} \mathrm{C}$ followed by $0: 45 \mathrm{~min} / 94^{\circ} \mathrm{C}, 0: 45 \mathrm{~min} / 54^{\circ} \mathrm{C}, 1: 30 \mathrm{~min} / 72^{\circ} \mathrm{C}$ for 35 cycles and final extension of $7 \mathrm{~min} / 72^{\circ} \mathrm{C}$. 3) $2 \mathrm{~min}$ at $94^{\circ} \mathrm{C}$ followed by $0: 30 \mathrm{~min} /$

\section{Table I}

ISSR primers screened for positive amplification in the total genomic DNA of A. astacus.

Tableau I

Amorces ISSR donnant une amplification positive à partir d'ADN total d'A. astacus.

\begin{tabular}{|l|c|c|c|c|c|}
\hline \multirow{2}{*}{$\begin{array}{c}\text { UBC Primer } \\
\text { Set \#9 }\end{array}$} & Primer structure & \multirow{2}{*}{$\begin{array}{c}\text { Number } \\
\text { of tested } \\
\text { primers }\end{array}$} & \multicolumn{3}{|c|}{ Amplification results } \\
\cline { 4 - 6 } $801-860$ & $\begin{array}{c}\text { 3'-anchored 2-base } \\
\text { repeats }\end{array}$ & 52 & 25 & 10 & 17 \\
\hline $861-881$ & $\begin{array}{c}\text { non-anchored 2-, 3- } \\
\text { or 4-base repeats }\end{array}$ & 21 & 11 & 6 & 4 \\
\hline $882-891$ & $\begin{array}{c}5 \text { '-anchored 2-base } \\
\text { repeats }\end{array}$ & 9 & 8 & 1 & 0 \\
\hline $892-900$ & $\begin{array}{c}\text { general genomic } \\
\text { amplification primers }\end{array}$ & 9 & 9 & 0 & 0 \\
\hline Total & & 91 & 53 & 17 & 21 \\
\hline
\end{tabular}

- any amplification products; + = poorly resolved banding pattern; ++ = clear-cut banding pattern.

\section{Table II}

ISSR primers used in the study, their sequences and applied annealing temperature for amplification.

Tableau II

Amorces ISSR utilisées : leurs séquences et température d'hybridation.

\begin{tabular}{|c|c|c|}
\hline Primer & Sequence & Annealing temperature \\
\hline UBC-808 & $(A G)_{8} C$ & Touch-down 60 to $52^{\circ} \mathrm{C}$ \\
\hline UBC-809 & $(A G)_{8} G$ & Touch-down 60 to $52^{\circ} \mathrm{C}$ \\
\hline UBC-812 & $(G A)_{8} A$ & $48^{\circ} \mathrm{C}$ \\
\hline UBC-815 & $(\mathrm{CT})_{8} \mathrm{G}$ & Touch-down 60 to $52^{\circ} \mathrm{C}$ \\
\hline UBC-841 & $(G A)_{8} Y C$ & Touch-down 60 to $52^{\circ} \mathrm{C}$ \\
\hline UBC-842 & $(G A)_{8} Y G$ & $54^{\circ} \mathrm{C}$ \\
\hline
\end{tabular}


$94^{\circ} \mathrm{C}, 0: 30 \mathrm{~min} / 60^{\circ} \mathrm{C}$ decreased by $0.5^{\circ} \mathrm{C}$ for each subsequent cycle, $0: 30 \mathrm{~min} / 72^{\circ} \mathrm{C}$ for 17 cycles, $0: 30 \mathrm{~min} / 94^{\circ} \mathrm{C}, 0: 30 \mathrm{~min} / 52^{\circ} \mathrm{C}, 0: 30 / 72^{\circ} \mathrm{C}$ for 23 cycles and a final extension of $7 \mathrm{~min} / 72^{\circ} \mathrm{C}$.

Each combination of primer and template DNA was repeated at least twice. A negative control (without template DNA) was added to every PCR run. Amplification products were separated according to size in $1.8 \%$ agarose gels in $0.5 \times$ TBE $(45 \mathrm{mM}$ Tris-borate, $1 \mathrm{mM}$ EDTA), stained with ethidium bromide and visualized with a UV transilluminator $(254 \mathrm{~nm})$. A $100 \mathrm{bp}$ DNA-ladder (ROTH, Germany) was included as size standard. Only strong bands which proved reproducible and polymorphic between populations were taken into account for further analysis. Each of these banding positions was considered a locus where phenotypes were scored as present (1) or absent (0).

As relative estimates of genetic diversity, the percentage of polymorphic loci and the Shannon's Index were calculated for individual populations using Popgene 1.32 (YEH, 1999). The genetic variation among populations was expressed as ROGERS' (1972) distance matrix. To determine if significant differences exist among populations the exact test for population differentiation was performed by using TFPGA 1.3 (MILLER, 1997). Hierarchical cluster dendrograms were obtained by UPGMA (Unweighted Pair Group Method with arithmetic Average) realised in the program TFPGA 1.3. Bootstrap values were calculated on the basis of 1000 permutations giving an estimation of confidence limits of the dendrogram.

\section{RESULTS}

Each of the six primers chosen for this study generated 11 to 18 distinguishable loci, resulting in 79 loci altogether. A total of 22 of them with a fragment size of 600 to $1800 \mathrm{bp}$ were reproducible over duplicates and polymorphic between individuals. Subsequent calculations are based on these 22 loci. As presented in Table III, the number

\section{Table III}

Genetic diversity estimates within populations of $A$. astacus using Shannon's information index (LEWONTIN, 1972).

\section{Tableau III}

Estimation de la diversité génétique au sein des populations d'A. astacus par l'indice de Shannon (LEWONTIN, 1972).

\begin{tabular}{|l|c|r|r|r|c|}
\hline \multirow{2}{*}{ Population } & \multirow{2}{*}{$\begin{array}{c}\text { Number of } \\
\text { specimens }\end{array}$} & \multicolumn{2}{|c|}{ Polymorphic loci } & \multicolumn{2}{c|}{$\mathbf{H}_{\mathbf{0}}$} \\
\cline { 3 - 6 } & $\mathbf{N}$ & [\%] & Mean & St. Dev. \\
\hline BB1 & 12 & 4 & 18.2 & 0.06 & 0.14 \\
\hline BY1 & 16 & 18 & 81.8 & 0.51 & 0.26 \\
\hline NW1 & 13 & 19 & 86.4 & 0.50 & 0.23 \\
\hline P1 & 15 & 4 & 18.2 & 0.10 & 0.23 \\
\hline P2 & 14 & 8 & 36.4 & 0.18 & 0.27 \\
\hline P3 & 14 & 4 & 18.2 & 0.09 & 0.20 \\
\hline P4 & 13 & 8 & 36.4 & 0.19 & 0.29 \\
\hline P5 & 14 & 11 & 50.0 & 0.23 & 0.28 \\
\hline Total & 111 & 22 & 100.0 & 0.43 & 0.15 \\
\hline
\end{tabular}


of polymorphic loci in one population ranged between 4 (18.2\%) and 19 (86.4\%). Lowest genetic diversities estimated by Shannon's Index were observed in BB1 $\left(H_{0}=0.06\right), P 1$ $\left(H_{0}=0.10\right)$ and P3 $\left(H_{0}=0.09\right)$, whereas BY1 $\left(H_{0}=0.51\right)$ and NW1 $\left(H_{0}=0.50\right)$ revealed highest levels of variation. The populations $\mathrm{P} 2\left(\mathrm{H}_{0}=0.18\right), \mathrm{P} 4\left(\mathrm{H}_{0}=0.19\right)$ and P5 $\left(\mathrm{H}_{0}=0.23\right)$ have an intermediate level of genetic diversity.

The UPGMA dendrogram obtained from pairwise ROGERS' distances revealed two main clusters (Figure 2). The population sampled in northeastern Germany (BB1) and all populations sampled in Poland formed an eastern group. The stock of North-Rhine Westphalia (NW1) and the stock of Bavaria (BY1) formed a western group. High bootstrap values, apart from one exception, indicated the robustness of the dendrogram (Figure 2). Pairwise comparisons of stocks between the two groups generally revealed significant differences (Table IV). Differences between stocks within the two groups were in some cases significant (e.g. BY1/NW1, P1/P4, P1/P5), suggesting potential sub-groups.

\section{DISCUSSION}

\section{Genetic variations in $A$. astacus}

Early genetic studies using protein electrophoresis suggested that freshwater crayfish species in general comprise an unusual low level of heterozygosity compared
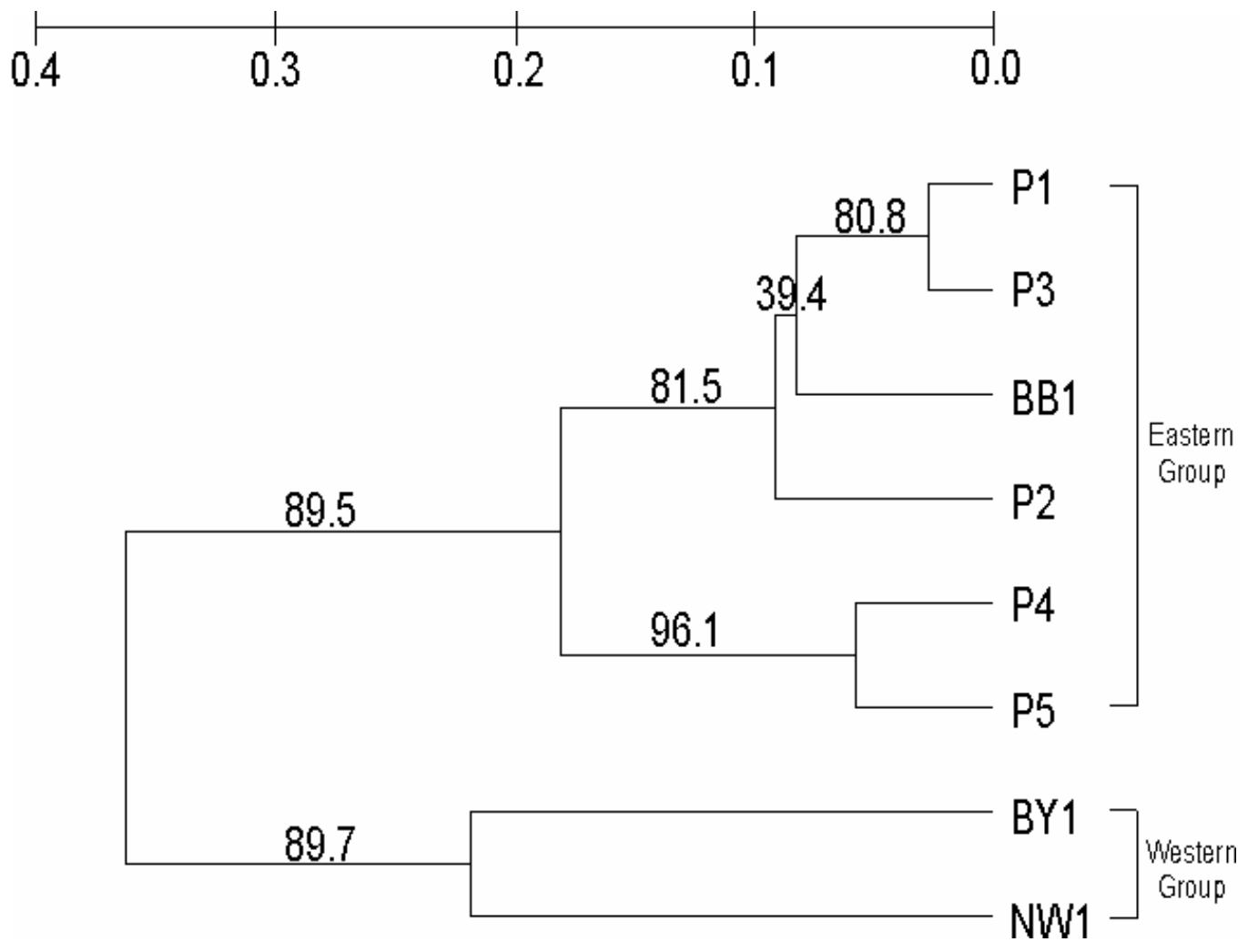

Figure 2

UPGMA cluster analysis of ROGERS' genetic distances. Numbers at the forks indicate bootstrap values.

Figure 2

Arbre de distance génétique de ROGERS (1972) selon la méthode UPGMA. 


\section{Table IV}

Matrix of ROGERS' (1972) genetic distance (below diagonal) and probability of genetic differentiation (above diagonal).

\section{Tableau IV}

Matrice des distances génétiques de ROGERS (1972) (au-dessous de la diagonale) et de probabilité de différenciation génétique (au-dessus de la diagonale).

\begin{tabular}{|l|c|c|c|c|c|c|c|c|}
\hline & BB1 & P1 & P2 & P3 & P4 & P5 & BY1 & NW1 \\
\hline BB1 & & 0.188 & 0.378 & 0.930 & 0.417 & 0.103 & 0.000 & 0.000 \\
\hline P1 & 0.097 & & 0.899 & 1.000 & 0.000 & 0.000 & 0.000 & 0.000 \\
\hline P2 & 0.087 & 0.086 & & 0.785 & 0.000 & 0.000 & 0.000 & 0.000 \\
\hline P3 & 0.069 & 0.027 & 0.102 & & 0.000 & 0.000 & 0.000 & 0.000 \\
\hline P4 & 0.119 & 0.215 & 0.174 & 0.188 & & 1.000 & 0.000 & 0.000 \\
\hline P5 & 0.141 & 0.224 & 0.183 & 0.201 & 0.058 & & 0.000 & 0.000 \\
\hline BY1 & 0.394 & 0.453 & 0.410 & 0.427 & 0.307 & 0.310 & & 0.000 \\
\hline NW1 & 0.338 & 0.419 & 0.371 & 0.392 & 0.280 & 0.249 & 0.218 & \\
\hline
\end{tabular}

to other invertebrates (CRANDALL, 1997). Data on allozymic variation of the species A. astacus had been published by FEVOLDEN and HESSEN (1989), AGERBERG (1990) and FEVOLDEN et al. (1994). AGERBERG (1990) found no genetically interpretable variation in any of the four $A$. astacus populations sampled in Sweden and Poland, whereas FEVOLDEN and HESSEN (1989) and FEVOLDEN et al. (1994) observed significant intersample heterogeneity at two polymorphic loci in $A$. astacus populations sampled in Norway. As stated by FEVOLDEN et al. (1994), present-day Norwegian crayfish populations were most probably introduced from Sweden. Detected differences could therefore originate from genetically differentiated founders (FEVOLDEN et al., 1994). Differences between populations of $A$. astacus with common ancestors were most likely caused by founder effects and genetic drift (FEVOLDEN and HESSEN, 1989). Contribution of selective constraints could not be excluded, although no meaningful correlation between abiotic or biotic factors or exploitation level on one hand and allelic variation on the other hand was found.

SCHULZ (2000) and EDSMAN et al. (2002) were the first to apply molecular genetic markers to evaluate genetic differentiation between populations of the noble crayfish. SCHULZ (2000) analysed the genetic structure of five stocks of the noble crayfish in Germany by means of RAPD-PCR. All five stocks were distinct, although their geographical separation was as small as $20 \mathrm{~km}$. The differences between stocks located close together were smaller than those between more distant stocks. However, it was not possible to determine whether low genetic variation found among individuals within a given stock was due to environmental constraints or genetic drift as result of a small population size. EDSMAN et al. (2002) examined 15 populations of $A$. astacus in Sweden and two in the former Yugoslavia. When tested with microsatellite-like markers in the ITS1 region, different populations revealed characteristic fragment patterns. Therefore, it was possible to differentiate most of them significantly. But HARRIS and CRANDALL (2000) as well as EDSMAN et al. (2002) noted intragenomic variation of the ITS regions of freshwater crayfish. This feature may obscure relationships at the population level, limiting the applicability of this technique for detailed phylogenetic reconstructions.

The pairwise genetic distances calculated on the basis of the ISSR markers in this study revealed significant differences between most of the populations examined. 
The UPGMA analysis divided two major clusters with hints for further subgroupings within these clusters. The results therefore indicate a geographical structuring of genetic differences. In agreement with observations made by SCHULZ (2000), nearby stocks in one region are more closely related to each other than to those in other regions. The existence of metapopulations, regional adaptations and/or differentiated ancestors may explain this pattern.

Levels of diversity assessed by ISSR markers were found to vary within a wide range. The highest levels were detected within the stocks of the two crayfish hatcheries. The stock BY1 was founded by mixing material taken from 4 different locations belonging to the Danube drainage system. Although these populations are situated within a radius of $150 \mathrm{~km}$, they are completely isolated from each other nowadays (M. Keller, pers. comm.). Most likely, the high level of variation of BY1 is caused by high variation of differentiated donor populations. In contrast to the hatchery stocks, three of the sampled populations (BB1, P1, P3) exhibited relatively low within-population variation. The former population of the noble crayfish in lake P3 disappeared due to changes in the anthropogenic water extraction. In 1996 the lake was restocked with approximately 1300 adult specimens of an equal sex ratio taken from P2 without knowing if the former population was completely extinct. In 2001 the total number of adult crayfish was estimated at about 630 specimens (unpublished data). Low level of diversity observed in P3 may be due to a prolonged bottleneck effect associated with reintroducing the noble crayfish in this lake and a small population size over several generations. The loss of variance depends largely on the effective population size (FRANKEL and SOULÉ, 1981). Nevertheless, the extent of the observed reduction is surprising. On theoretical grounds, FRANKLIN (1980) and SOULÉ (1980) predicted that an effective population size of 500 specimens is needed to maintain genetic variability in quantitative characters in the long term. As shown by other authors, this "rule of thumb" is questionable and lacks the realism to be useful in species management (FOLEY, 1992; BEISSINGER and WESTPHAL, 1998). It can be assumed that a large quantity of the founder population did not survive or did not reproduce successfully. Lakes BB1 and P1 are vital and dense populations but population size is restricted by lake size, namely 0.7 and 1.5 ha respectively. Stock sizes were estimated at about 600 adult crayfish (6 700 specimens in total) in lake BB1 (SCHULZ and SYPKE, 1999) and 3250 adult crayfishes (unpublished data) in lake $\mathrm{P} 1$, respectively. A small population size increases the risk of inbreeding and the loss of genetic variation (BOOY et al., 2000).

Further research is needed to answer the question to what extent geographical structuring of the noble crayfish populations is due to translocation events or due to the history of natural colonization and on the basis of this knowledge to define autochthonous populations. A combined assessment of population size, habitat quality and genetic diversity would help to evaluate the significance of environmental constraints or genetic drift with respect to genetic differentiation of noble crayfish populations.

\section{Managing genetic biodiversity}

The survival of a population or a whole species depends on several factors. In the short term, genetic variation is supposedly of minor importance, but in the long term genetic variation is essential for the ability of a population to adapt to changing environmental conditions (FRANKEL and SOULÉ, 1981; BOOY et al., 2000). Therefore, management of a species must include the conservation of its genetic diversity.

A major problem in managing noble crayfish populations is the fragmentation of habitats and the resulting isolation of populations. For several reasons it is not advisable to try to restore the migration of the noble crayfish by creating corridors. This may facilitate the distribution of severe diseases like crayfish plague as well as the invasion of non-indigenous crayfish species or predatory fish such as eel. An alternative strategy to counteract the still ongoing loss of natural crayfish populations might be the protection 
and habitat enhancement of existing stocks and founding of new stocks by reintroduction into habitats where they have previously lived or introduction into new habitats. A crucial question for any restocking measures is the origin of restocking material, as highlighted by SCHULZ et al. (2002). As shown in this study, the noble crayfish populations are geographically structured, which may be the result of environmental constraints leading to local adaptations. BOOY et al. (2000) recommended that special attention should be paid to populations with specific genetic variations (e.g. populations in marginal habitats or at the borders of the geographic range), which therefore may be of specific value for maintenance of the long-term evolutionary perspectives for these species. To conserve the overall genetic variation of the noble crayfish (composed of within- and betweenpopulation variation) it is recommended to conduct restocking programs on a local basis. A first and essential step is the definition of conservation units on the basis of significant genetic differences. In this study the ISSR technique proved to be an appropriate tool to reveal differences between stocks of $A$. astacus. As second step, estimations of stock size and quality in regard to diseases in combination with the assessment of genetic diversity allow the selection of appropriate donor populations within those units. To ascertain a minimum of genetic variety, strong populations with high heterozygosity or genetic variation are preferable (FEVOLDEN et al., 1994). Crayfish hatcheries could play an important role in managing the noble crayfish. Where natural populations are too small to serve as donor for restocking material or catching is restricted, crayfish hatcheries may take over the role of breeding stocks of different regions. They can provide sufficient amounts of restocking material, which is produced under controlled conditions, and checked for diseases and parasites.

\section{ACKNOWLEDGEMENTS}

We would like to thank Harald Wendt, Josef Kroy, the administration of the Landkreis Uckermark for intensive cooperation and the Landesumweltamt Brandenburg that authorized the crayfish sampling in Brandenburg. Carsten Burk and Dr. Max Keller have been valuable sources for providing material from other crayfish stocks and background information. Dr. Kai Metge and Dr. Frédéric Grandjean are thanked for their helpful suggestions concerning the methodology. Financial support was provided by the Stiftung für Bildung und Behindertenförderung, Stuttgart.

\section{BIBLIOGRAPHIE}

ABBOT P., 2001. Individual and population variation in invertebrates revealed by Intersimple Sequence Repeats (ISSRs). Journal of Insect Science, 1.8. Available online: www.insectscience.org/1.8

AGERBERG A., 1990. Genetic variation in three species of freshwater crayfish, Astacus astacus L., Astacus leptodactylus Aesch. and Pacifastacus leniusculus (Dana), revealed by isozyme electrophoresis. Hereditas, 113, 101-108.

ALBRECHT H., 1983. Besiedlungsgeschichte und ursprüngliche holozäne Verbreitung der europäischen Flusskrebse. Spixiana, 6, 61-77.

ATTARD J., VIANET R., 1985. Variabilité génétique et morphologique de cinq populations de l'écrevisse européenne Austropotamobius pallipes (Lereboullet 1858) (Crustacea, Decapoda). Canadian Journal of Zoology, 63, 2933-2939.

AVISE J.C., 1994. Molecular markers, Natural History and Evolution. Chapman and Hall (eds.), New York.

BEISSINGER S.R., WESTPHAL M.I. 1995. On the use of demographic models of population viability in endangered species management. Journal of Wildlife Management, 62, 821-841. 
BOOY G., HENDRIKS R.J.J., SMULDERS M.J.M., VAN GROENENDAEL J.M., VOSMAN B., 2000. Genetic diversity and the survival of populations. Plant biology, 2, 379-395.

BORNET B., BRANCHARD M., 2001. Nonanchored Inter Simple Sequence Repeat (ISSR) Markers: reproducible and specific tools for genome fingerprinting. Plant Molecular Biology Reporter, 19, 209-215.

CRANDALL K.A., 1997. Genetic variation within and among crayfish species. Freshwater Crayfish, 11, 135-145.

DEHUS P., PHILLIPSON S., BOHL E., OIDTMANN B., KELLER M., LECHLEITER S., 1999. German conservation strategies for native crayfish species with regard to alien species. In: Crayfish in Europe as alien species. How to make the best of a bad situation? GHERARDI F., HOLDICH D.M., (Eds.), 149-159, A.A. Balkema, Rotterdam.

FERGUSON M.M., 1990. The genetic impact of introduced fishes on native species. Canadian Journal of Zoology, 68 (5), 1053-1057.

FETZNER J.W., CRANDALL K.A., 1999. Genetic variability within and among populations of the golden crayfish (Orconectes luteus): a comparison using amplified fragment length polymorphism (AFLPs) and mitochondrial 16s gene sequences. Freshwater Crayfish, 12, 396-412.

FEVOLDEN S.E., HESSEN D.O., 1989. Morphological and genetic differences among recently founded populations of noble crayfish (Astacus astacus). Hereditas, 110, 149-158.

FEVOLDEN S.E., TAUGBØL T., SKURDAL J., 1994. Allozymic variation among populations of noble crayfish, Astacus astacus L., in southern Norway: implications for management. Aquaculture and Fisheries Management, 25, 927-935.

FOLEY P., 1992. Small population genetic variability at loci under stabilizing selection. Evolution, 46, 763-774.

FRANKEL O.H., SOULÉ M.E., 1981. Conservation and evolution. Cambridge University Press, Cambridge, USA.

FRANKLIN I.R., 1980. Evolutionary changes in small populations. In: SOULÉ M.E. and WILCOX B.A. (eds.), Conservation biology: an evolutionary-ecological perspective, 135-149, Sinaur Associates, Sunderland, Massachusetts, USA.

GOUIN N., GRANDJEAN F., SOUTY-GROSSET C., 2000. Characterization of microsatellite loci in the endangered freshwater crayfish Austropotamobius pallipes (Astacidae) and their potential use in other decapods. Molecular Ecology, 9 (5), 636-637.

GOUIN N., GRANDJEAN F., BOUCHON D., REYNOLDS J.D., SOUTY-GROSSET C., 2001. Population genetic structure of the endangered freshwater crayfish Austropotamobius pallipes, assessed using RAPD markers. Heredity, 87, 80-87.

GOUIN N., SOUTY-GROSSET C., ROPIQUET A., GRANDJEAN F., 2002. High dispersal ability of Austropotamobius pallipes revealed by microsatellite markers in a French brook. Bull. Fr. Pêche Piscic., 367, 681-689.

GUPTA M., CHYI Y.-S., ROMERO-SEVERSON J., OWEN J.L., 1994. Amplification of DNA markers from evolutionarily diverse genomes using single primers of simplesequence repeats. Theoretical and Applied Genetics, 89, 998-1006.

GRANDJEAN F., SOUTY-GROSSET C., 2000. Mitochondrial DNA variation and population genetic structure of the white-clawed crayfish, Austropotamobius pallipes pallipes. Conservation Genetics, 1, 309-319. 
GRANDJEAN F., HARRIS D.J., SOUTY-GROSSET C., CRANDALL K.A., 2000. Systematics of the European endangered crayfish species Austropotamobius pallipes (Decapoda: Astacidae). Journal of Crustacean Biology, 20 (3), 522-529.

GRANDJEAN F., GOUIN N., SOUTY-GROSSET C., DIEGUEZ-URIBEONDO J., 2001. Drastic bottlenecks in the endangered crayfish species Austropotamobius pallipes in Spain and implications for its colonization history. Heredity, 86 (4), 431-438.

HAASE T., HEIDECKE D., KLAPPERSTÜCK J., 1989. Zur Ökologie und Verbreitung des Edelkrebses Astacus astacus in der DDR. Hercynia N. F., 26, 36-57.

HAIG S., 1998. Molecular contributions to conservation. Ecology, 79 (2), 413-425.

HARRIS D.J., CRANDALL K.A., 2000. Intragenomic variation within ITS1 and ITS2 of freshwater crayfishes (Decapoda: Cambaridae): Implications for phylogenetic and microsatellite studies. Molecular Biology and Evolution, 17 (2), 284-291.

HINDAR K., RYMAN N., UTTER F., 1991. Genetic effects of cultured fish on natural fish populations. Canadian Journal of Fisheries and Aquatic Sciences, 48, 945-957.

HOLDICH D.M., 2002. Distribution of crayfish in Europe and some adjoining countries. Bull. Fr. Pêche Piscic., 367, 611-650.

KARAMAN M., 1962. Ein Beitrag zur Systematik der Astacidae. Crustaceana, 3, 173-201.

LARGIADER C.R., HERGER F., LÖRTSCHER M., SCHOLL A., 2000. Assessment of natural and artificial propagation of the white-clawed crayfish (Austropotamobius pallipes species complex) in the Alpine region with nuclear and mitochondrial markers. Molecular Ecology, 9 (1), 25-37.

KIRBY L.T., 1990. DNA-Fingerprinting : an introduction. Stockton Press, New York.

MACARANAS J.M., MATHER P.B., HOEBEN P., CAPRA M.F., 1995. Assessment of genetic variation in wild populations of the redclaw crayfish (Cherax quadricarinatus, von Martens 1868) by means of allozyme and RAPD-PCR markers. Marine and Freshwater Research, 46, 1217-1228.

MILLER M.P., 1997. Tools for population genetic analysis (TFPGA) 1.3: A Windows program for the analysis of allozyme and molecular population genetic data. Distributed by the author. http://bioweb.usu.edu/mpbio/index.htm

MORITZ C. 1994. Defining evolutionarily significant units for the conservation. Trends in Ecology and Evolution, 9, 373-375.

MUNASINGHE D.H.N., MURPHY N.P., AUSTIN C.M., 2003. Utility of mitochondrial DNA sequences from four gene regions for systematic studies of Australian freshwater crayfish of the genus Cherax (Decapoda: Parastacidae). Journal of Crustacean Biology, 23 (2), 402-417.

RIFFEL M., SCHREIBER A., 1995. Coarse-grained population structure in Central European sculpin (Cottus gobio L.): secondary contact or ongoing genetic drift? Journal for Zoological Systematics and Evolutionary Research, 33, 173-184.

ROGERS J.S., 1972. Measures of genetic similarity and genetic distance. University of Texas Studies in Genetics, 7, 145-153.

SAMBROOK J., RUSSELL D.W., 2001. Molecular cloning : a laboratory manual. Cold Spring Habor Laboratory Press, New York.

SCHULZ R., 2000. Status of the noble crayfish Astacus astacus (L.) in Germany: monitoring protocol and the use of RAPD markers to assess the genetic structure of populations. Bull. Fr. Pêche Piscic., 356, 123-138. 
SCHULZ R., SYPKE J., 1999. Freshwater crayfish populations Astacus astacus (L.) in Norteast Brandenburg (Germany): Analysis of Genetic Structure using RAPD-PCR. Freshwater Crayfish, 12, 387-395.

SCHULZ R., STUCKI T., SOUTY-GROSSET C., 2002. Management: reintroductions and restocking. Bull. Fr. Pêche Piscic., 367, 917-922.

SKAALA O., DAHLE G., JORSTAD K.E., NAEVDAL G., 1990. Interactions between natural and farmed fish populations: information from genetic markers. Journal of Fish Biology, 36, 449-460.

ŚMIETANA P., KRZYWOSZ T., STRUŻYŃSKI W., 2003. Review of the national restocking programme "Active protection of native crayfish in Poland" 1999-2001. Bull. Fr. Pêche Piscic., 372-373, 57-67.

SOULÉ M.E., 1980. Thresholds for survival: maintaining fitness and evolutionary potential. In: SOULÉ M.E. and WILCOX B.A. (eds.), Conservation biology: an evolutionaryecological perspective, 151-170, Sinaur Associates, Sunderland, Massachusetts, USA.

SOUTY-GROSSET C., GRANDJEAN F., RAIMOND R., FRELON M., DEBENEST C., BRAMARD M., 1997. Conservation genetics of the white-clawed crayfish Austropotamobius pallipes: the usefulness of the mitochondrial DNA marker. Bull. Fr. Pêche Piscic., 347, 677-692.

VIGNEUX E., THIBAULT M., MARNELL F., SOUTY-GROSSET C., 2002. National legislation, EU directives and conservation. Bull. Fr. Pêche Piscic., 367, 887-898.

WOLFE A.D., LISTON A., 1998. Contributions of PCR-based methods to plant systematics and evolutionary biology. In: SOLTIS D.E., SOLTIS P.S., DOYLE J.J. (eds.), Molecular systematics of Plants II: DNA Sequencing, 43-86, Kluwer, New York.

YEH F.C., 1999. Popgene, v. 1.32. Distributed by the author. http://www.ualberta.ca/ fyeh/ index.htm

ZIĘTKIEWICZ E., RAFALSKI A., LABUDA D., 1994. Genome fingerprinting by simple sequence repeat (SSR)-anchored polymerase chain reaction amplification. Genomics, 20, 176-183. 
